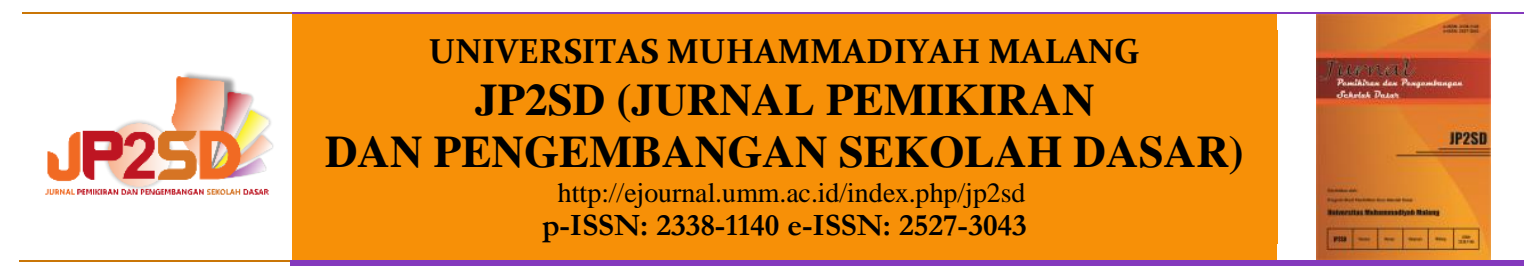

\title{
Model Pembelajaran Numbered Heads Together (NHT): Pengaruh Terhadap Hasil Belajar Tematik Siswa SD
}

\author{
Fauzatul Ma'rufah Rohmanurmeta
}

PGSD, FKIP, Universitas PGRI Madiun, Indonesia

fauzatul@unipma.ac.id

\begin{tabular}{ll}
\hline INFORMASI ARTIKEL \\
\hline Riwayat: & \\
Diterima & 14 Agustus \\
& 2020 \\
Revisi & 10 September \\
& 2020 \\
Dipublikasikan & 26 September \\
& 2020
\end{tabular}

Kata kunci:

Model NHT, Hasil Belajar, pembelajaran Tematik

\begin{abstract}
ABSTRAK
Penciptaan interaksi agar siswa aktif dapat dilakukan melalui model pembelajaran. Penelitian ini bertujuan untuk mengetahui pengaruh model pembelajaran Numbered Heads Together (NHT) terhadap hasil belajar tematik siswa kelas IV SDN Nglayang 1 tahun 2018/2019. Jenis penelitian ini adalah kuantitatif dengan eksperimen sebagai metode penelitian. Populasi dalam penelitian ini adalah seluruh siswa SD Negeri 1 Nglayang dan SD Negeri 2 Nglayang kelas IV yang masing-masing berjumlah 22 dan 23 siswa. Dengan sampel menggunakan teknik sampling jenuh, sehingga sampel berjumlah 45 siswa. Data hasil belajar tematik diperoleh dari teknik tes berupa pilihan ganda. Analisis data diuji menggunakan uji-t. Analisis selisih rata-rata diperoleh tobs $=6,77 \alpha=0,05$ dan $\mathrm{DK}=\{\mathrm{t}$ $\mid \mathrm{t}<-2.07$ atau $\mathrm{t}>2.07\}$. Berdasarkan data tersebut dapat disimpulkan bahwa terdapat pengaruh model pembelajaran Numbered Heads Together (NHT) terhadap hasil belajar tematik.
\end{abstract}

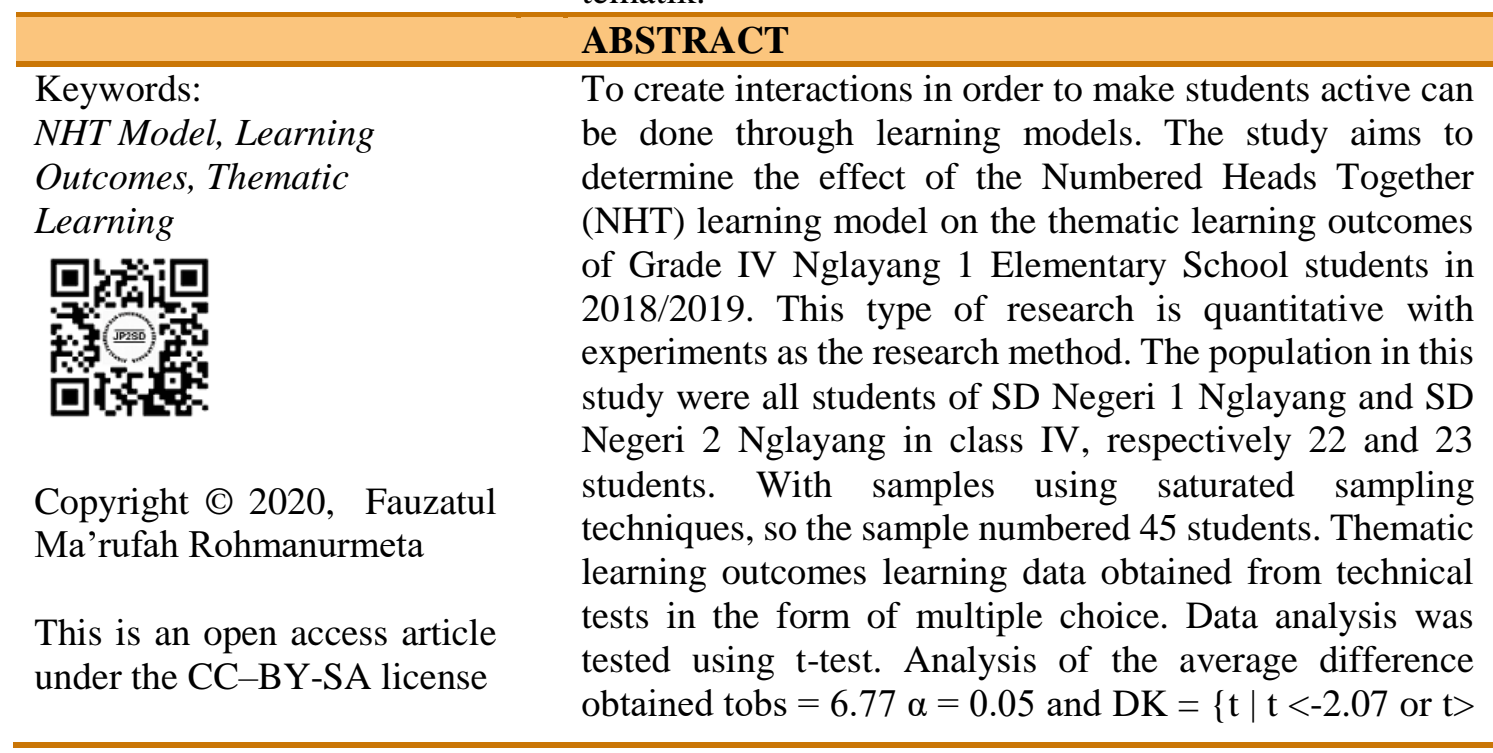



an influence of the Numbered Heads Together (NHT) learning model on the thematic learning outcomes.

How to cite: Fauzatul Ma'rufah Rohmanurmeta. (2020). Model Pembelajaran Numbered Heads Together (NHT): Pengaruh Terhadap Hasil Belajar Tematik Siswa SD. Jurnal Pemikiran dan Pengembangan Sekolah Dasar, Vol 8 No 2, 163-169. doi: 10.22219/jp2sd.v8i2.14086

\section{PENDAHULUAN}

Pendidikan merupakan suatu wadah untuk membentuk manusia yang berpotensi. Semakin tinggi kualitas pendidikan maka semakin tinggi pula potensi sumber daya manusia. Begitu juga sebaliknya semakin rendah kualitas pendidikan maka semakin rendah pula potensi sumber daya manusia. Potensi sumber daya manusia diukur dari segi kognitif, afektif, dan psikomotorik . Pengukuran ketiga ranah ini terdapat dalam pembelajaran tematik.

Pembelajaran tematik merupakan suatu pembelajaran yang mengintegrasikan beberapa mata pelajaran kedalam satuan tema. Tidak hanya aspek kognitif saja yang diterapkan dalam pembelajaran tematik namun apek keterampilan dan sikap juga diutamakan. Aspek sikap mmuat hubungan manusia dengan manusia dan hubungan manusia dengan tuhan. Ketiga ranah ini harus diintegrasikan dalam kegiatan pembelajaran untuk meningkatkan kemampuan belajar siswa. Kemampuan belajar siswa dapat di lihat dari adanya hasil belajar siswa pada pembelajaran tematik. Kenyataan dilapangan menunjukkan terdapat berbagai permasalahan dalam pembelajaran tematik. Guru tidak mampu mengintegrasikan ranah afektif, kognitif, dan psikomotorik dalam kegiatan pembelajaran. Selain itu pada aspek religius juga terabaikan. Banyak guru kelas yang mengabaikan aspek keagamaan dalam kegiatan pembelajaran. Guru juga terbiasa menggunakan model pembelajaran konvensional sehingga siswa merasa bosan dan jenuh ketika mengikuti kegiatan pembelajaran. Siswa merasa tidak tertarik dalam kegiatan belajar yang menyebabkan hasil belajar rendah. Rendahnya hasil belajar dapat dilihat dari nilai hasil belajar siswa SD Negeri Nglayang ketika ujian akhir semester memiliki ratarata 67. Nilai rata-rata ini masih tergolong rendah karena berada dibawah KKM 75.

Rendahnya hasil belajar siswa dapat teratasi dengan menggunakan model pembelajaran Numbered Heads Together (NHT). Karena model pembelajaran Numbered Heads Together (NHT) dapat melibatkan kemampuan, keterampilan, dan sikap siswa dalam kegiatan pembelajaran sehingga mampu meningkatkan hasil belajar siswa. Hasil belajar merupakan bentuk hasil kemampuan belajar peserta didik yang dinyatakan dengan nilai hasil ulangan. Hal ini disebabkan rasa bosan, tidak suka pada gurunya, rasa tertekan atau memang pembelajaran tematik itu sulit untuk dipahami, dan juga penggunaan model pembelajaran yang kurang tepat. Di sisi lain guru cenderung menempatkan siswa sebagai obyek pembelajaran sehingga siswa pasif dalam proses kegiatan belajar di kelas. Jadi ada dua faktor yang dapat menyebabkan rendahnya hasil belajar dan lemahnya karakter religius yaitu dari siswa maupun dari guru itu sendiri.

Salah satu usaha untuk meningkatkan hasil belajar siswa berbasis karakter religius adalah dengan mengubah kegiatan pembelajaran. Kegiatan pembelajaran yang sebelumnya bersifat teacher center diubah dengan kegiatan pembelajaran student center. Kegiatan pembelajaran yang bersifat student center terdapat pada model pembelajaran numbered heads together (NHT). Dewi, R.D., Prihandono, T., \&. Handayani, D.R. (2016:49) menjelskan bahwa model pembelajaran Numbered Head Together (NHT) adalah suatu bentuk cara belajar secara berkelompok yang dirancang secara terstruktur

Fauzatul Ma'rufah Rohmanurmeta. Model Pembelajaran Numbered Heads Together (NHT): Pengaruh Terhadap Hasil Belajar Tematik Siswa SD 
dalam bentuk pembelajaran dikelas dengan kerjasama antara 4-5 siswa dalam suatu kelompok serta mendapatkan reward berdasarkan keberhasilan hasil kerjanya.Sedangkan model pembelajaran numbered heads together (NHT) merupakan model pembelajaran kooperatif dengan mengutamakan kreatifitas siswa yang mengandung unsur kegamaan untuk mencari, mengolah, dan melaporkan informasi, kemudian menyaikan hasil didepan kelas.

Berdasarkan berbagai macam permasalahan diatas model pembelajaran numbered heads together (NHT) sangat tepat digunakan dalam pembelajaran tematik khususnya pada tema berbagai macam pekerjaan. Mulyana, M.A., Hanifah, N., \&. Jayadinata, A.K. (2016:334) menjelaskan bahwa jenis model pembelajaran ini menjadikan kegiatan pembelajaran yang menyenangkan, karena siswa dapat saling bertukar pendapat dengan teman-temannya untuk meyelesaikan suatu permasalahan. Model pembelajaran ini dapat melatih keterampilan dan sikap siswa dalam berinteraksi dengan temannya untuk mencari solusi dari suatu permasalahan sehingga membuat siswa menyadari akan perbedaan antara teman satu dengan teman yang lainnya. Peningkatan keterampilan dan sikap siswa yang meningkat dalam suatu kegiatan pembelajaran akan diikuti peningkatan kognitif siswa dalam kegiatan pembelajaran sehingga hasil belajar siswa akan meningkat.

Agus Purwanto (2016:37) menjelaskan bahwa hasil belajar merupakan kompetensi yang didapatkan peserta didik dari hasil pembelajaran. Hasil belajar siswa sebagai suatu tujuan dilaksanakannya kegiatan pembelajaran pada tingkat satuan pendidikan Mardiah Kalsum (2017:9). Sedangkan Sembiring (2018:74) menjelaskan bahwa berdasarkan penjelasan tersebut sebagai seorang guru diharapkan mampu mengemas suatu model pembelajaran yang menarik untuk meningkatkan hasil belajar peserta didik. Hasil belajar yang diperoleh peserta didik sangat penting dalam pendidikan karena merupakan suatu bentuk ukuran keberhadilan peserta didik dalam mengikuti jalannya sistem pendidikan. Terdapat beberapa hal yang dapat berpengaruh terhadap hasil pembelajaran, diantaranya adalah faktor dari dalam dan faktor dari luar. Faktor dari dalam diantaranya adalah kemampuan berpikir, minat dan bakat, aktifitas, serta kemampuan belajar. Sedangkan dari luar diantaranya adalah lingkungan keluarga, sekolah,dan masyarakat.

Pembelajaran terpadu atau pembelajaran tematik adalah suatu bentuk perbaikan yang dihasilkan ilmuwan dibidang pendidikan pada tahun 1989 yang bernama Jacob dengan menggunakan pendekatan interdisipliner dalam kegiatan pembelajaran. Selain itu pada tahun 1989 Fogarty mengembangkan konsep pembelajaran tematik dengan pendekatan terpadu. Adib Rifqi (2020:51) menjelaskan bahwa pembelajaran tematik merupakan suatu metode pembelajaran yang lebih mengutamakan sajian tema dalam proses pembelajaran. Pembelajaran tematik adalah sebagai bentuk sudut pandang yang dilaksanakan dalam kegiatan pembelajaran dengan mengintegrasikan berbagai macam bahan dalam suatu mata pelajaran ataupun antar mata pelajaran yang disajikan dalam bentuk tema. Andanya keterpaduan tersebut siswa bisa mendapatkan berbagai macam kemampuan dalam bentuk kognitif, aektif, maupun psikomotorik dalam satu kesatuan yang membuat kegiatan pembelajaran menjadi sangat bermakna bagi siswa.

Indriani (2015:89) menjelaskan bahwa pelaksanaan kegiatan pembelajaran secara tematik dilaksanakan melalui beberapa tahapan, yaitu: 1) rencana, 2) pelaksanaan, 3) evaluasi. Pada kegiatan rencana pendidik memetakan kompetensi dasar, memilih tema yang akan diambil, menganalisis indikator, kemudian menyusun silabus dan RPP. Kemudian pada tahapan pelaksanaan kegiatan belajar mengajar dilaksanakan dengan menggunakan model pembelajaran Numbered Heads Together (NHT). Model 
pembelajaran ini membuat peserta didik dapat belajar dan bermain sehingga siswa akan merasa sangat gembira. Sedangkan tahap evaluasi dilaksanakan untuk melihat pengaruh keberhasilan kegiatan pembelajaran setelah menggunakan model pembelajaran Numbered Heads Together (NHT) atau yang disebut dengan kegiatan pembelajaran bernomor.

Model pembelajaran Numbered Heads Together menurut Chellyana \& Siswanto (2015:91) adalah suatu bentuk pembelajara berkelompok yang disusun untuk membentuk hubungan antar siswa dalam suatu kelas terhadap jalannya pembelajaran. Model kegiatan pembelajaran bernomor ini dikenalkan tokoh yang bernama Spencer kagan. Model pembelajaran ini menyediakan peluang bagi peserta didik agar dapat mengemukakan gagasan-gagasan dengan mempertimbangkan berbagai macam solusi jawaban yang sangat tepat. Model pembelajaran ini mendukung peserta didik agar mampu mengembangkan motivasi dan kerjasama dalam belajar. Berdasarkan penelitian yang dilakukan oleh Yuni F., Karlimah, \&., Ahmad M., menunjukkan bahwa model pembelajaran NHT memiliki pengaruh yang positif terhadap hasil belajar siswa, sehingga perlu diterapkan dalam kegiatan pembelajaran.

Suprijono (2015:111) menjelaskan bahwa kegiatan pembelajaran dengan memanfaatkan model number head together dimulai dengan penomoran. Pendidik membagi peserta didik dalam kelas kedalam beberapa kelompok kecil. Banyaknya kelompok disesuaikan dengan banyaknya materi yang akan dibahas dalam kegiatan pembelajaran. Jumlah siswa dalam suatu kelas terdiri dari 20 siswa dan dibagi kedalam 4 kelompok sesuai dengan jumlah materi pelajaran yang akan bahas, maka setiap kelompok memiliki jumlah anggota 5 siswa. Setiap siswa ditandai dengan nomor 1-5. Penomoran diberikan dengan menggunakan angka Arab. Kemudian setelah kelompok sudah terbentuk maka pendidik mengajukan berbagai macam pertanyaan bermuatan karakter religius yang wajib dijawab oleh masing-masing kelompok yang ada dalam kelas tersebut. Pendidik memberikan kesempatan pada masing-masing kelompok untuk menggabungkan kepala "Heads Together" untuk mencari dan mendapatkan solusi atau penyelesaian dari permasalahan yang disajikan guru. Selanjutnya pendidik yang mendapatkan kesamaan nomor pada masing-masing kelompok diminta untuk mempresentasikan hasil solusi atau penyelesaian dari permasalahan yang telah disajikan.

\section{METODE}

Tempat pelaksanaan penelitian ini dilakukan di SD Negeri Nglayang yang terletak di wilayah kecamatan Jenangan Kabupaten Ponorogo pada tahun ajaran 2018/2019. Jenis penelitian ini merupakan penelitian kuantitatif dengan metode penelitian yang yang digunakan yaitu quasi eksperimen dengan model desain group statis. Pada kelas eksperimen diberi perlakuan dengan menerapkan model NHT. Sedangkan pada kelas kontrol diberi perlakuan dengan menggunakan model pembelajaran yang biasa guru gunakan yaitu model pembelajaran konvensional. Populasi yang terdapat pada penelitian ini yaitu semua peserta didik pada jenjang kelas IV SDN I Nglayang dan SD Negeri II Nglayang. Teknik pengambilan sampel dilakukan dengan sampling jenuh. Dengan jumlah sampel SDN 1 Nglayang berjumlah 22 dan SDN 11 Nglayang berjumlah 23. Terdapat dua jenis variabel pada penelitian ini yaitu variabel bebas dan variabel terikat. Model pembelajaran NHT merupakan variabel bebas yang terdapat pada penelitian ini, sedangkan variabel terikatnya yaitu hasil belajar pada pembelajaran tematik.

Tes uji coba pada instrumen penelitian dilakukan dengan langkah-langkah yaitu uji validitas, uji reliabilitas, uji analisis daya beda, uji tingkat kesukaran. Pelaksanaan uji

Fauzatul Ma'rufah Rohmanurmeta. Model Pembelajaran Numbered Heads Together (NHT): Pengaruh Terhadap Hasil Belajar Tematik Siswa SD 
hipotesis yang dilaksanakan dengan uji-t (t-test) yang sebelumnya dilakukan uji normalitas sebagai uji prasarat dengan metode lliefors dan uji homogenitas menggunakan analisis uji-F dengan signifikansi $5 \%$.

\section{HASIL DAN PEMBAHASAN}

Hasil data yang diperoleh dalam penelitian ini terdiri atas nilai siswa kelompok eksperimen siswa kelas IV SD Negeri 01 Nglayang dengan jumlah siswa 22 menggunakan model pembelajaran NHT adalah nilai rata-rata siswa 87,5 dengan median a90, modus 90, dan standar deviasi 11,10. Sedangkan pada data kelas kontrol yang dilaksanakan pada sisws kelas IV SD Negeri 02 Nglayang dengan jumlah siswa 23 dengan tanpa menggunakan model pembelajaran NHT adalah nilai rata-rata siswa 61,96 dengan median 65 , modus 65 , dan standar deviasi 13,8 .

Berdasarkan data nilai hasil belajar tersebut, maka nilai peseta didik pada kelompok eksperimen dan kelompok kontrol digambarkan dalam grafik sebagai berikut:

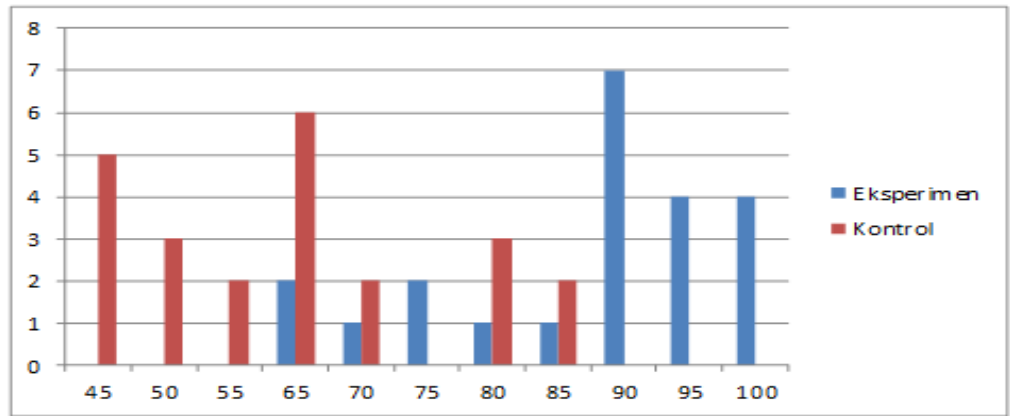

\section{Grafik 1. Perbandingan hasil nilai siswa kelas eksperimen dan kontrol}

Sebelum dilakukan pengujian hipotesis dengan uji-t, diperlukan uji prasyarat terlebih dahulu. Uji prasyarat yang dilakukan adalah uji normalitas untuk melihat apakah sampel yang didapatkan dari populasi berdistribusi normal atau tidak, dan uji homogenitas untuk melihat kesamaan varian dari data yang didapatkan. Uji normalitas dianalisis menggunakan menggunakan metode liliefors dengan taraf signifikansi $5 \%$. Adapun hasil yang diperoleh pada uji normalitas disajikan pada tabel 1.

Tabel 1. Hasil analisis uji normalitas.

\begin{tabular}{lrll}
\hline Kelas & $\mathrm{L}_{\mathrm{obs}}$ & $\mathrm{L}_{\text {tabel }} / \mathrm{DK}$ & Kesimpulan \\
\hline Eksperimen & 0,129 & $\mathrm{DK}=$ & $\mathrm{H}_{0}$ diterima \\
& & $\{\mathrm{L} \mid \mathrm{L}>0,190\}$ & \\
\hline Kontrol & 0,156 & $\mathrm{DK}=$ & $\mathrm{H}_{0}$ diterima \\
& & $\{\mathrm{L} \mid \mathrm{L}>0,190\}$ & \\
\hline
\end{tabular}

Dari tabel 1 di atas terlihat bahwa pada uji normalitas didapatkan bahwa nilai peserta didik pada kelompok eksperimen yang berjumlah 22 data dengan signifikansi sebesar 5\%, dan $\mathrm{DK}=0,190$ menunjukkan bahwa $\mathrm{L}_{\mathrm{obs}}=0,129$ sehingga data dinyatakan berdistribusi normal karena $\mathrm{L}_{\mathrm{obs}}$ tidak terletak atau melebihi pada daerah kritik. Pada uji normalitas hasil nilai peseta didik pada kelompok kontrol yang berjumlah 23 data dengan signifikansi sebesar 5\% serta $\mathrm{DK}=0,190$ didapatkan $\mathrm{L}_{\mathrm{obs}}=0,156$. Berdasrkan hasil tersebut menunjukkan bahwa data yang diperoleh berdistribusi normal, hal ini disebabkan karena $\mathrm{L}_{\mathrm{obs}}$ tidak terletak atau melebihi dartah kritik. 
Hasil analisis data uji homogenitas dengan menggunakan uji $\mathrm{F}$ dengan tingkat sisgnifikan $\mathrm{a}=0,05$, dari data hasil tes formatif ditunjukkan pada tabel 2.

Tabel 2. Hasil analisis uji homogenitas

\begin{tabular}{cccr}
\hline $\mathrm{F}_{\text {hitung }}$ & $\mathrm{F}_{\text {tabel }}$ & Kriteria & Keputusan Uji \\
\hline 1,55 & 2,04 & $\mathrm{~F}_{\text {hitung }} \leq \mathrm{F}_{\text {tabel }}$ & $\mathrm{H}_{0}$ diterima \\
\hline
\end{tabular}

Berdasarkan tabel 2 dapat diketahui adanya hasil uji homogenitas yang didapatkan $F_{\text {hitung }}=1,55$, sedangkan $F_{\text {tabel }}=2,04$. Analisis tersebut dengan didasarkan pada kriteria $\mathrm{H}_{0}=\mathrm{F}_{\text {hitung }} \leq \mathrm{F}_{\text {tabel, }}, 1,55 \leq 2,04$. Hasil data yang diperoleh berarti $\mathrm{H}_{0}$ diterima, Berdasarkan hasil tersebut bisa ditarik kesimpulan bahwa sampel yang didapatkan berasal dari populasi yang sama.

Analisis uji hipotesis pada penelitian ini dilakukan dengan menggunakan uji-t. Hasil analisis uji hipotesis didapatkan $t_{\text {hitung }}=6,77$ dan $t_{\text {tabel }}=2,07$. Hasil analisis data tersebut didasarkan pada kriteria keputusan $\mathrm{H}_{0}$ ditolak jika $\mathrm{t}_{\text {hitung }}>\mathrm{t}_{\text {tabel }}$ dan $\mathrm{H}_{0}$ diterima jika $t_{\text {hitung }} \leq \mathrm{t}_{\text {tabel. }}$. Berdasarkan analisis tersebut dapat ditarik kesimpulan Bahwa $\mathrm{H}_{0}$ ditolak. Hal ini disebabkan karena thitung $>t_{\text {tabel }}$ atau 6,77 $>2,07$.

Berdasarkan data hasil uji hipotesis bisa ditarik kesimpulan bahwa terdapat perbedaan pada hasil belajar pembelajaran tematik peserta didik dengan menerapkan model pembelajaran NHT (kelas eksperimen) dibandingkan dengan peserta didik yang diajar dengan menerapkan model pembelajaran konvensional. Perbedaan pertama ditunjukkan pada hasil nilai rata-rata peserta didik ketika dilakukannya post test. Setelah diterapkan model pembelajaran NHT dalam pembelajaran tematik pada siswa kelas IV SDN 1 Nglayang diperoleh nilai rata-rata siswa sebesar 87,5. Sedangkan siswa kelas IV SDN 2 Nglayang dengan menggunakan model pembelajaran konvensional mendapatkan hasil nilai rata-rata sebesar 61,9. Jadi hasil belajar dengan menggunakan model NHT memiliki hasil yang lebih tinggi dibandingkan dengan hasil belajar menggunakan model konvensional.

Perbedaan yang kedua adalah pada aktivitas kegiatan belajar mengajar. Ketika peneliti menggunakan model pembelajaran NHT pada pembelajaran tematik di kelas IV SDN 1 Nglayang Kecamatan Jenangan Kabupaten Ponorogo, peserta didik melakukan kegiatan pembelajaran secara aktif dengan penuh perhatian dan konsentrasi pada materi yang dipelajari. Peserta didik menjadi lancar dengan penuh kepercayaan diri ketika menjawab pertanyaan yang disajikan peneliti. Peserta didik juga lebih tertarik dalam mengikuti kegiatan pembelajaran. Hal itu bisa diketahui dengan adanya minat peserta didik yang sangat tinggi pada proses belajar mengajar sehingga siswa mudah menerima materi pelajaran. Sedangkan ketika peneliti mengadakan penelitian dengan model konvensional pada pembelajaran tematik di kelas IV SDN 2 Nglayang Kecamatan Jenangan Kabupaten Ponorogo, siswa terlihat pasif, ramai dengan disertai minat belajar yang rendah. Peserta didik juga terlihat bingung dalam menjawab pertanyaan dari peneliti karena penyampaian materi sulit diterima siswa dan kurang menarik minat siswa untuk memperhatikannya.

Jadi model pembelajaran NHT mampu menarik minat siswa untuk mengikuti proses belajar dari pada proses belajar dengan menggunakan model pembelajaran konvensional. Dari pembahasan di atas menunjukkan bahwa kelompok yang menerapkan model pembelajaran NHT berbeda dengan kelompok yang menggunakan model pembelajaran konvensional. Nilai rata-rata dan aktivitas belajar mengajar dengan

Fauzatul Ma'rufah Rohmanurmeta. Model Pembelajaran Numbered Heads Together (NHT): Pengaruh Terhadap Hasil Belajar Tematik Siswa SD 
menggunakan model pembelajaran NJHT berbasis religius jauh lebih baik dibanding kelas yang menerapkan model pembelajaran konvensional.

\section{SIMPULAN}

Berdasarkan analisis hasil penelitian dan pembahasan maka bisa ditarik kesimpulan bahwa terdapat pengaruh yang positif dan signifikan penggunaan model pembelajaran Numbered Heads Together (NHT) terhadap hasil belajar tematik pada tema berbagai pekerjaan siswa kelas IV SDN I Nglayang Kecamatan Jenangan Kabupaten Ponorogo tahun pelajaran 2018/2019. Berdasarkan data tersebut dapat disimpulkan bahwa terdapat pengaruh model pembelajaran Numbered Heads Together (NHT) terhadap hasil belajar tematik.

\section{REFERENSI}

Chellyana, K.W., \&. Siswanto, S. (2015). Implementsi Model Pembelajaran Kooperatif Numbered Heads Together (NHT) untuk Meningkatkan Prestasi Belajar. Jurnal Pendidikan Akuntansi Indonesia. Vol. 13. No. 2, hlm 89-96.

Dewi, R.D., Prihandono, T., \&. Handayani, D.R. (2016). Penerapan Model Pembelajaran Kooperatif Tipe Number Head Together (NHT) Disertai Metode Eksperimn pada Pembelajaran Fisika Kelas X di SMA Negeri Arjasa. Jurnal Pembelajaran Fisika. Vol.5 No.1, hlm 47-52.

Indriani, F. (2015). Kompetensi Pedagogik Mahasiswa Dalam Mengelola Pembelajaran Tematik Integratif Kurikulum 2013 pada Pengajaran Micro di PGSD UAD Yogyakarta. Profesi Pendidikan Dasar Vol. 2. No. 2, hlm 87-94.

Mulyana, M.A., Hanifah, N., \&. Jayadinata, A.K. (2016). Penerapan model Kooperatif Tipe Numbered Heads together (NHT) untuk Meningkatkan Hasil Belajar Siswa pada Materi Kenampakan Alam dan Sosial Budaya. Jurnal pena Ilmiah. Vol. 1, No. 1, hlm 331-340.

Nasution, M. K. (2018). Penggunaan metode pembelajaran dalam peningkatan hasil belajar siswa. Studia Didaktika, 11(01), 9-16.

Purwanto, A. (2016). Peningkatan Aktivitas dan Hasil Belajar Siswa Pada Mata Pelajaran IPA dengan Menggunakan Metode Examples Non Examples Di Kelas VIIh SMP 5 Kudus Semester II Tahun Pelajaran 2014/2015. Jurnal Profesi Keguruan, 2(1), 36-41.

Sembiring, M. A., Sibuea, M. F. L., \& Sapta, A. (2018). Analisa Kinerja Algoritma C. 45 Dalam Memprediksi Hasil Belajar. Journal Of Science and Social Research, 1(1), 73-79.

Setiawan, A. R. (2020). Pembelajaran Tematik Berorientasi Literasi Saintifik. Jurnal Basicedu, 4(1), 51-69.

Suprijono, Agus. (2015). Cooperative Learning. Yogyakarta; Pustaka Pelajar.

Yuni, F., Karlimah., \&. Ahmad, M. (2018). Pengaruh Model Pembelajaran NHT Terhadap Hasil Belajar Siswa pada Materi Perjuangan Melawan Penjajahan . Jurnal Ilmiah Pendidikan Guru Sekolah Dasar. Vol. 5. No. 2, hlm 129-14 